\title{
ESTIMACION DE LA TALLA DE PRIMERA MADUREZ SEXUAL DE LA CACHEMA Cynoscion analis (YENYNS) DURANTE EL PERIODO DE MAXIMA ACTIVIDAD REPRODUCTIVA
}

Esperanza López C. y Hilda. Caramantín S.

Universidad Ricardo Palma

\section{RESUMEN}

A pesar de la significación que tiene la "cachema" Cynoscion analis (YENYNS) cabe indicar que los trabajos de investigación relacionados a los aspectos reproductivos son muy pocos, destacando sin duda el trabajo realizado por Samamé (1971), quien analizó la madurez sexual y desove de la cachema en la zona de Paita.

El objetivo de este estudio fue estimar la talla de primera madurez sexual y talla al primer desove de la cachema durante el periodo de máxima actividad reproductiva, en un intento de aportar información básica de la especie en dicha área. Para tal efecto el material biológico fue obtenido de la Caleta de Chorrillos durante el periodo de setiembre de 1998 agosto de 1999, analizándose 302 ejemplares entre machos y hembras.

Para evitar una sub o sobrestimación de la talla de primera madurez sexual, se determinó la época principal de mayor actividad reproductiva a través del Indice Gonadosomático y evolución de los estadíos de madurez sexual (Caramantín, 1998). En la determinación de la talla de primera madurez sexual se aplicó el modelo logístico de Balbotin y Fisher (1981) y para estimar la talla al primer desove el método de frecuencia acumulada de Mendo (1984).

Los resultados obtenidos muestran que la talla de primera madurez sexual es a los 22 $\mathrm{cm}$ de longitud y de 22,5 y $23,0 \mathrm{~cm}$ de longitud para hembras y machos respectivamente. Con respecto a la talla al primer desove es a los $27 \mathrm{~cm}$ de longitud.

Se concluye que las talla de primera madurez sexual es mayor a la establecida para la zona de Paita y que la principal actividad reproductiva corresponde a los meses de verano y primavera.

Palabras Claves: Cynoscion analis, Indice Gonadosomático, estadíos, desove

\section{SUMMARY}

In spite of the significance that has the "cachema" Cynoscion analis it is necessary to indicate that the investigation works related to the reproductive aspects are very few, highlighting the work by Samamé (1971) who analyzed the sexual maturity and spawn of the cachema in the area of Paita.

The objective of this study was to estimate the size of first sexual maturity and the size of the first it spawns of the cachema during the period of maximum reproductive activity, in an intent of contributing basic information of the species in this area. For such an effect the biological material was obtained of the Chorrillos of Caleta during the period of September of 1998- August of 1999, being analyzed 302 individuals between males and females.

To avoid a sub-estimation e or overestimation of the size of first sexual maturity, the main time of more reproductive activity was determined through the Index Gonadosomático and evolution of the states of sexual maturity (Caramantín, 1998). In the determination of the size of first sexual maturity it was applied the logistical pattern of Balbotin and Fisher (1981) and to estimate the size at the first it spawns the method of accumulated frequency of Mendo (1984).

The obtained results show that the size of first sexual maturity is to the $22 \mathrm{~cm}$ of longitude and of 22,5 and $23,0 \mathrm{~cm}$ of longitude for females and males respectively. With regard to the size at the first spawns it is to the $27 \mathrm{~cm}$ of longitude. 
The conclusion that the size of first sexual maturity is bigger to the established one for the area of Paita and that the main reproductive activity corresponds to the months of summer and spring.

Key Words: Cynoscion analis, Index Gonadosomático, estadíos estadíos, spawns

\section{INTRODUCCION}

En la zona central del Perú, la "cachema" Cynoscion analis es capturada por la pesquería artesanal, siendo la caleta de Chorrillos una de las zonas de abastecimiento de pescado fresco al mercado interno.

Su agradable sabor y valor nutritivo hacen de esta especie un recurso de gran importancia para la alimentación popular.

A pesar de la significación que tiene la cachema, cabe indicar que los trabajos de investigación relacionados a los aspectos reproductivos son muy pocos, destacando sin duda el trabajo realizado por Samamé (1971), quien analizó la madurez sexual y desove de la cachema en la zona de Paita. Asimismo el de Alvitres (1979) y Gonzáles (1981) quienes estimaron la madurez sexual y fecundidad de la cachema respectivamente.

En el presente trabajo se estimará la talla de primera madurez sexual de la cachema durante el periodo de máxima actividad reproductiva, en un intento de aportar información básica de la especie en dicha área.

\section{MATERIAL Y METODOS}

El material biológico empleado fue obtenido en la Caleta de Chorrillos (Fig. 1) durante Setiembre de 1998 - Agosto de 1999, analizándose 302 ejemplares entre machos y hembras. Luego de obtenidas las muestras se procedió a medir y examinar a cada ejemplar, registrándose los siguientes datos: longitud total, peso total, peso eviscerado, sexo, estadío sexual, peso de las gónadas y longitud de las gónadas respectivamente.

La identificación de los estadios de madurez sexual se obtuvo mediante un análisis macroscopico, empleando para tal fin la escala de Johansen (1919).

$$
\text { Para evitar una sub o }
$$
sobrestimación de la talla de primera madurez sexual, se determinó la época principal de mayor actividad reproductiva a través del Indice Gonadosomático y evolución de los estadios de madurez sexual (Caramantín, 1998).

Para obtener la talla de primera madurez sexual se consideró los estadios del III al VIII, determinando la clase de talla en el que el $50 \%$ de hembras y machos están maduros. Una vez obtenida la frecuencia de madurez por clase de tallas se aplicó el modelo logístico de Balbotín y Fisher (1981).

La talla al primer desove se determinó utilizando el método de frecuencia acumulada (Mendo, 1984)donde se incluye a los ejemplares que se encuentran en los estadios V al VII.

\section{RESULTADOS}

De acuerdo a la evolución de la madurez sexual y el Indice Gonadosomático se establece un periodo de máxima actividad reproductiva, correspondiente a las estaciones de primavera y verano con un pico máximo del Indice Gonadosomático durante los meses de diciembre de 1998 y enero de 1999 (Fig. 2 y 3 ).

La talla de primera madurez sexual para ambos sexos obtenida a través del modelo logístico es de $22 \mathrm{~cm}$ de longitud, y de 22,5 y $23,0 \mathrm{~cm}$ de longitud para hembras y machos respectivamente. (Fig. 4, 5 y 6 ).

En las Figuras 7, 8 y 9 se puede observar que el $50 \%$ de los ejemplares alcanzan la talla al primer desove a los 27,5 $\mathrm{cm}$ de longitud, siendo $27,3 \mathrm{~cm}$ de longitud para machos y $27,6 \mathrm{~cm}$ de longitud para hembras.

\section{DISCUSION}

Con respecto a la época principal de desove de la cachema los resultados obtenidos concuerdan con Mendo (Op. cit) 
en que la época principal de desove es durante la primavera y verano, sin embargo es importante mencionar que las variaciones mensuales del ciclo de desove de la cachema posiblemente estaría influenciado por los cambios de temperatura adelantándose o retrasándose el desove (Caramantín Op. cit).

En relación a la talla de primera madurez sexual, los resultados no concuerdan con los de Samamé (Op. Cit.), debido posiblemente a los criterios de madurez gonadal utilizado por cada autor. Asimismo probablemente a las diferentes fechas de puestas que darán lugar a diferentes reclutamientos anuales.

\section{REFERENCIAS BIBLIOGRAFICAS}

1. ALVITRES, V. 1979. Madurez sexual y relación peso - longitud de Cynoscion analis "cachema" durante el verano de 1974, Caleta Santa Rosa Lambayeque. Rev. Científica $\mathrm{N}^{\circ} 1$ Univ. Nac. "Pedro Ruiz Gallo". Lambayeque - Perú. 43-52.

2. BALBOTIN, F y FICHER, W. 1981. Ciclo sexual y fecundidad de la merluza (Merluccius gayi gayi). En la Costa Norte de Chile. Rev. Biol. Mar Inst. Oceanol. Univ. De Valparaíso. Chile, 17(3): 285-234.
3. CARAMANTIN, H. 1998. Algunos aspectos reproductivos y su relación del Factor de Condición de Scomber japonicus peruanus (Jordán y Hubb, 1925) Teleostomi: Scombridae) en la zona norte $y$ centro del litoral peruano durante 1990-1991. Tesis UPRP, Lima Perú, $50 \mathrm{p}$.

4. GONZALES, F. 1981. Madurez sexual y fecundidad de Cynoscion analis "cachema" Tesis Lic. Biol. Pesq. Univ. Nac. "Pedro Ruiz Gallo". Lambayeque - Perú, 61 p.

5. MENDO, J. 1984. Edad, crecimiento $\mathrm{y}$ algunos aspectos reproductivos y alimenticios de la caballa, Scomber japonicus peruanus. Bol. Inst. Mar Perú Callao, Perú, 8(4): 101-156.

6. SAMAME, M. 1971. Observaciones de la madurez sexual y desove de la cachema Cynoscion analis (YENYNS) de Paita. Inf. Inst. Mar, IM -81, Callao - Perú, 29-39. 